\title{
Analysis of Students' Stages in Solving Vector Concept Problems in Different Contexts
}

\author{
Nur Afni \\ Physics Education \\ Universitas Tadulako \\ Palu, Indonesia \\ Jusman Mansyur \\ Physics Education \\ Universitas Tadulako \\ Palu, Indonesia \\ jusman_mansyur@untad.ac.id
}

\author{
Yusuf Kendek \\ Physics Education \\ Universitas Tadulako \\ Palu, Indonesia
}

\begin{abstract}
This research was aimed to analyze and describe students' stages in solving vector concept problems in different contexts. Subjects of the research were 34 students of a high school in Palu. Research data were collected by testing and interviews. Interviewed respondents were six students and they represented three categories of ability in a respondents selection testing. The data were analyzed by the descriptive-qualitative approach. Results of the research showed that the students' stages and ability in solving the vector problems with no context were better than for the problems with physics context. There is a tendency of representation bias from the two contexts of the problems.
\end{abstract}

Keywords: problem-solving, vector concept problems in different contexts.

\section{INTRODUCTION}

Mathematics has a closed connection to physics. Mathematics is logical science in the form of composition, size, and concepts related to each other in large numbers. Mathematics can be connected properly with laws of physics. In the context of mathematics and physics, the vector is material that often found in many cases. There are many concepts in physics that can be expressed by the vector.

Several researches on problem-solving have been done by researchers [2], [3], [4], [5]. These researchs focused on the application of mathematical problem solving of Polya. Ref.[6] have examined the solving physics stages associated with the use of representations. Ref. [7] compared the students' understanding in solving concept problems of the vector. The study used the concept of the vector without context and physics context. Results of the research showed differences of abilities of respondents.

Our research aimed to analyze the steps of students in problem-solving. The research used the test in the context of the transfer of learning. It included physics context vector (VwP) and vector without context (VwC). The test included parallelogram, algebra and analytical method.

\section{METHOD}

The research applied qualitative-descriptive approach. Subjects of the research were 34 students of a high school in Palu. All subjects were involved in solving ten essay problems. From the subjects, we conducted respondent selection for involving in interviews. Interviewed respondents were six students and they represented three categories (high, moderate, and low) of ability (Table 1).

TABLE 1. INTERVIEWED RESPONDENTS OF THE RESEARCH

\begin{tabular}{|c|c|c|c|}
\hline No. & Respondent & Category & Code \\
\hline 1 & R-33 & High & RT-01 \\
\hline 2 & R-19 & High & RT-02 \\
\hline 3 & R-31 & Moderate & RS-01 \\
\hline 4 & R-16 & Moderate & RS-02 \\
\hline 5 & R-13 & RR-01 \\
\hline 6 & R-7 & Low & RR-02 \\
\hline
\end{tabular}

To obtain a score of problem-solving stages, we used a rubric from Analytical Scale for Problem Solving [8]. Data of the research were analyzed by applying qualitative-descriptive approach.

\section{RESULTS AND DISCUSSION}

Results of the students' scores of in the problem solving the stages are presented in Fig. 1. The picture is a qualitative comparison of average scores of $\mathrm{VwP}$ and $\mathrm{VwC}$. 


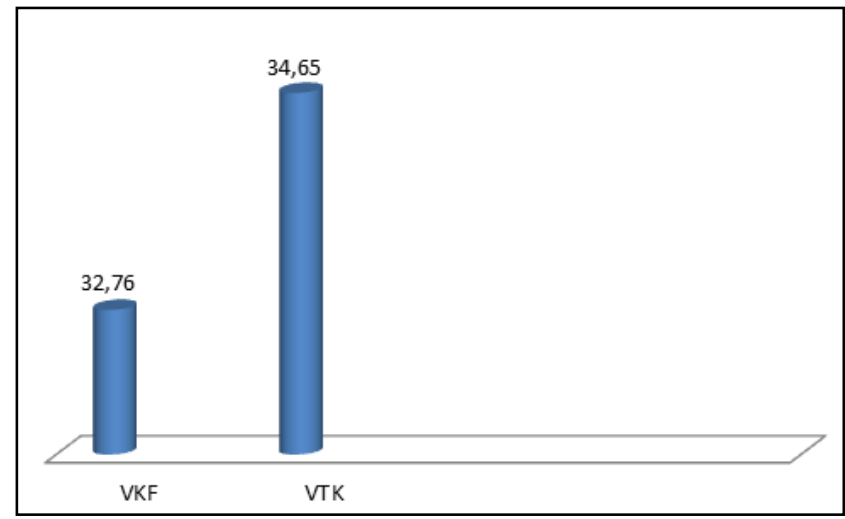

Fig. 1. Comparison of the average score of $\mathrm{VwP}_{w}$ and $\mathrm{VwC}$

Statistical analysis of the scores using parametric statistical of t-test for dependent samples shows significant $(\alpha=0,05)$ difference between students' score of VwP and VwC. Obtained scores of students on the $\mathrm{VwC}$ higher than on the VwP. It shows students easily solved the problems if there is no context including in the problems.

Respondents were unable to complete one stage of context with problem-solving fully within the framework of the transfer of learning. The planning stages in the vector problemsolving physics context show that six respondents were unable to present the answer in the form of a visual (picture). Instead, the planning stages of problem-solving on the part of the vector without context are represented in the form of an image showing all the respondents to present the answer in the form of equations. This is consistent with the statement of the NCTM (National Council of Teachers Mathematics) that representations can help teachers and students to develop, share and present real problem situations into mathematical language [8].

Research [6] compared the students' understanding of the concept of vectors without context and context vectors with three mechanics that style, speed, and work. Results the median of a multiple-choice test on a student obtained without context vectors and vector mechanics context there is no significant difference. A significant difference was found in the concept of mechanics context vector with several items. This is proven by a written explanation of student answers. Results were similar to results obtained from this study that the students do not understand the physics context vectors.

The weakness in this study is in the process of preparing the instrument. Researchers have difficulty in developing instruments that are arranged similarly to look at the steps problem of the student's solving.

Based on RT-01"s answer to VKF on No. 1 item shows that she can identify all the information including in the matter. When confirmed about the process of identifying variables, she says that "what you know the width of the river 18 meters, water velocity (water) $4 \mathrm{~m} / \mathrm{s}$, and the velocity (v) the boat to the water flow of $3 \mathrm{~m} / \mathrm{s}$. Then asked spacing $(R)^{\prime \prime}$.

RT-01 can not answer by measures appropriate problemsolving at the stage of solving the problem. When confirmed about the process of solving the problem, she said that"I wrote completion width multiplied by the speed of the boat to the water flow divided by the speed of the water". It shows that he does not understand the concept, especially in a straight motion of matter. In addition, the depiction or sketch of the information on the matter and the analysis of the images are not on the stage of solving the problem. When it is confirmed on the matter, she said that "I think I wrote all of that in mind, so no need to I described at the stage of completion".

RT-01 can identify some of the given information at the VTK. When confirmed about the process of identifying variables, she said that " $a$ vector $(|\vec{a}|)$ and the vector $b(|\vec{b}|)$ which is questioned me dressing as $F_{1}$ and F2. Then, the angle formed in the image is a right angle so I write cos $90^{\circ}$ is equal to 0 . The question asked in the resultant $(R)$ ".

RT-01 has not been able to answer correctly solving the problem-solving phase. When confirmed about the process of solving the problem, she said that "The formula I use $R$ equals to $\sqrt{F_{1}^{2}+F_{2}^{2}+2 . F_{1}+F_{2} \cos \theta}$. Then, I put the numbers up can result $5 N^{\prime \prime}$.

RT-01 changed $|\vec{a}|$ and $|\vec{b}|$ to $\mathrm{F}_{1}$ and $\mathrm{F}_{2}$ and did not leave the unit (Fig 1) at the stage of identification information. Furthermore, at this stage, it is not appropriate troubleshooting write the equation. She is also less appropriate to write unit on the end result.

The answer was written and interviews showed that respondents did not understand the concept and just glued to the formula that has been acquired in learning. Depictions or sketch is very important at this stage of problem-solving for the depiction of respondents easier to analyze a given problem. This is evident in the process of understanding the VTK where the part is available pictures. Answer RT-01 at No. 1 can be seen in Fig 2.

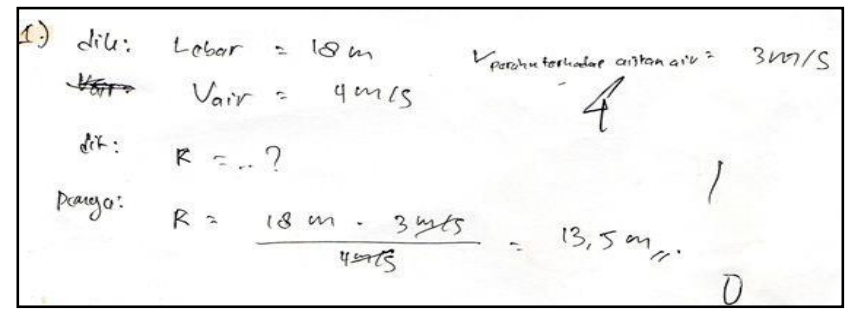

(a)

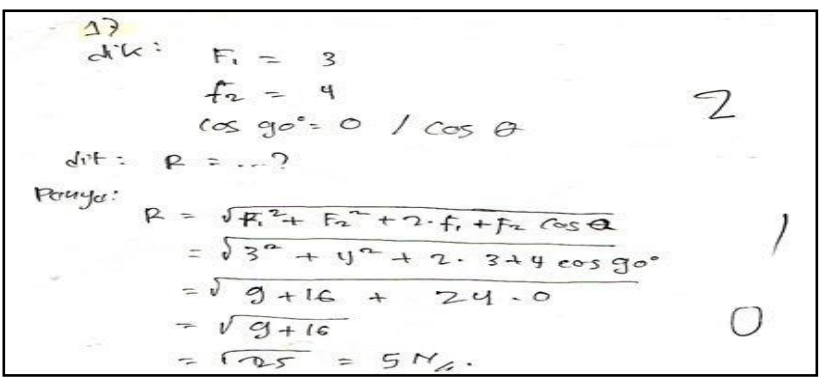

(b)

Fig. 2. Answer RT-01 on VKF (a) and VTK (b)

Answers to VTK on item No. 1 part VKF, RT-02 can identify all of the information provided on the matter. When 
confirmed about the process of identifying variables, she said that "the known width of the river is $18 \mathrm{~m}$, water velocity $\left(\mathrm{v}_{\text {water }}\right) 4 \mathrm{~m} / \mathrm{s}$ and the speed of the boat $\left(\mathrm{v}_{\text {boat }}\right) 3 \mathrm{~m} / \mathrm{s}$. Asked mileage boat."

RT-02 can not be answered by measures appropriate problem-solving. When confirmed about the process of solving the problem, she said that "I finish by multiplying the width of the river with boat speed, then dividing by the speed of the water". The depiction or drawing sketches and analysis of the information in question was not found in the stage of solving the problem. She is also less appropriate to write unit on the end result.

RT-02 only identify some of the information given on the VTK. When confirmed the identification process variable, she said that "what you know $F_{1}$ the 3 units $F_{2}$ was 4 units and the angle $(\theta)$ was $90^{\circ}$. So $|\vec{a}|$ and $|\vec{b}|$ I exist in a matter of replacing as $F_{1}$ and $F 2$. I use an angle of $90^{\circ}$ as the angle of the picture bracket. Asked the resultant $(R)^{\prime \prime}$. At this stage of the identification information, it changes $|\vec{a}|$ and $|\vec{b}|$ to $\mathrm{F}_{1}$ and $\mathrm{F}_{2}$ but he is correct in giving the unit.

RT-02 is not yet right to write the equation for VTK at the stage of solving the problem. When confirmed the problemsolving process she said that "I used to finish the formula $R$ equals $\sqrt{F_{1}^{2}+F_{2}^{2}+2 . F_{1}+F_{2} \cos \theta}$, I input the numbers so that the result is $5 \mathrm{~N}^{\prime \prime}$. At the stage of answering the question, it is less appropriate in the write unit on the end result.

Based on written answers and interviews, the RT-02 does not understand the concept in both parts of the vector that served researchers and simply glued to the formula that they've got in the learning process. Of the two forms of vectors which are presented to researchers, she can understand the shape of VTK. When confirmed about it, she said that "Without No.1 part Vectors larger context I understand". Answer RT-02 at No. 1 can be seen in Fig 3.

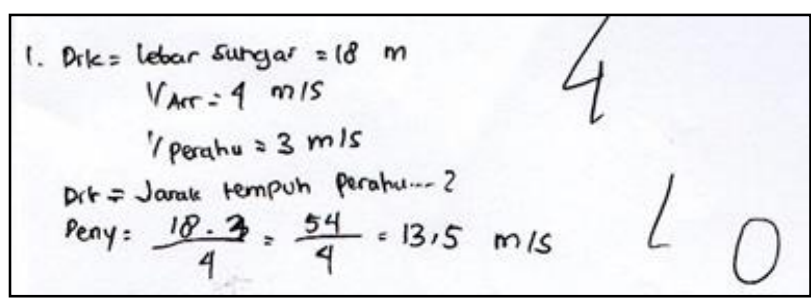

(a)

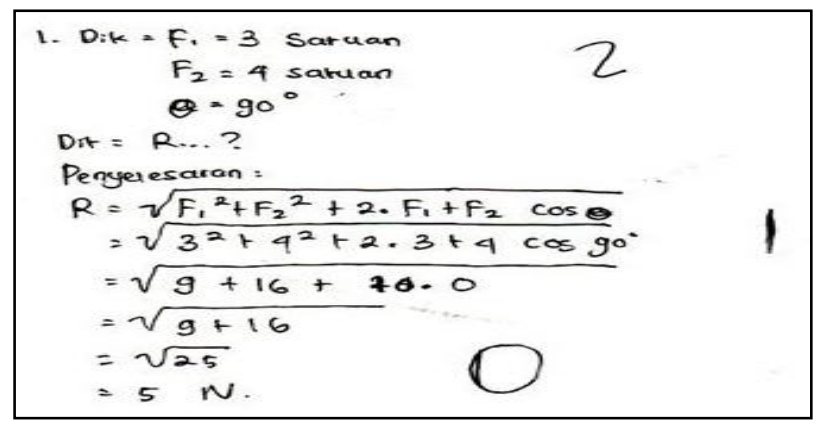

(b)

Fig. 3. Answer RT-02 on VKF (a) and VTK (b)
Step-by-step problem solving of each respondent is presented in Table 4. In the table showing the use steps problem solving of VKF and VTK.

Table IV shows that measures problem solving of VTK more leverage used by the respondent. This indicates that the VTK better understood by respondents, although the views of the accuracy of answers to every measures problem solving of each respondent have not been right overall.

Respondents were unable to complete one stage of context with problem-solving fully within the framework of the transfer of learning. The planning stages in the vector problemsolving physics context show that six respondents were unable to present the answer in the form of a visual (picture). Instead, the planning stages of problem-solving on the part of the vector without context are represented in the form of an image showing all the respondents to present the answer in the form of equations. This is consistent with the statement of the NCTM (National Council of Teachers Mathematics) that representations can help teachers and students to develop, share and present real problem situations into mathematical language.

TABLE IV. CHARACTERISTICS OF STEP PROBLEM SOLVING

\begin{tabular}{|c|c|c|c|}
\hline $\begin{array}{l}\text { Step of } \\
\text { Problem } \\
\text { Solving }\end{array}$ & & Description & Respondent \\
\hline \multirow{2}{*}{$\begin{array}{l}\text { Identification } \\
\text { information }\end{array}$} & VKF & $\begin{array}{l}\text { There is identification } \\
\text { information and } \\
\text { respondents were able to } \\
\text { identify most of the } \\
\text { information provided }\end{array}$ & $\begin{array}{l}\text { RT-01, RS-01, RT- } \\
\text { 02, and RS-02 }\end{array}$ \\
\hline & VTK & $\begin{array}{l}\text { There is identification } \\
\text { information and } \\
\text { respondents were able to } \\
\text { identify some of the } \\
\text { information given }\end{array}$ & $\begin{array}{l}\text { RT-01, RS-01, RR- } \\
\text { 01, RT-02, RS-02 } \\
\text { and RR-02 }\end{array}$ \\
\hline \multirow{2}{*}{$\begin{array}{l}\text { Planning in } \\
\text { problem-solving }\end{array}$} & VKF & \multirow{2}{*}{$\begin{array}{l}\text { There is a plan to solve } \\
\text { the problem, but the } \\
\text { equations used by the } \\
\text { respondent has not right }\end{array}$} & RT-01 and RS-02 \\
\hline & VTK & & $\begin{array}{l}\text { RT-01, RS-01, } \\
\text { RR-01, RT-02, } \\
\text { RS-02 and RR-02 }\end{array}$ \\
\hline \multirow{2}{*}{$\begin{array}{l}\text { Solution to } \\
\text { problem }\end{array}$} & VKF & \multirow{2}{*}{$\begin{array}{l}\text { There is a problem } \\
\text { solving, but respondents } \\
\text { can not be answered by } \\
\text { the steps appropriate } \\
\text { problem solving }\end{array}$} & RT-01 and RS-02 \\
\hline & VTK & & $\begin{array}{l}\text { RT-01, RS-01, } \\
\text { RR-01, RT-02, } \\
\text { RS-02 and RR-02 }\end{array}$ \\
\hline \multirow{2}{*}{$\begin{array}{c}\text { Looking back at } \\
\text { the results } \\
\text { obtained }\end{array}$} & VKF & \multirow{2}{*}{$\begin{array}{l}\text { Respondents look back at } \\
\text { the results obtained }\end{array}$} & \multirow{2}{*}{$\begin{array}{l}\text { RT-01, RS-01, and } \\
\text { RS-02 }\end{array}$} \\
\hline & VTK & & \\
\hline
\end{tabular}

Research [7] compared the students' understanding of the concept of vectors without context and context vectors with three mechanics that style, speed, and work. Results the median of a multiple-choice test on a student obtained without context vectors and vector mechanics context there is no significant difference. A significant difference was found in the concept of mechanics context vector with several items. This is proven by a written explanation of student answers. Results were similar to results obtained from this study that the students do not understand the physics context vectors. 
The weakness in this study is in the process of preparing the instrument. Researchers have difficulty in developing instruments that are arranged similarly to look at the steps problem of the student's solving.

\section{CONCLUSION}

Based on the results of data analysis we concluded that the use of stage of problem-solving a complete used by students as a part of a vector without context. The cause is easier to work on the problems of students who are visually represented in the form of an image rather than a matter that is not represented visually.

\section{REFERENCES}

[1] I. E. Studies, "The Implementation of the Polya Method in Solving Euclidean Geometry Problems," vol. 7, no. 7, pp. 149-158, 2014.
[2] S. Yuan, "Pólya_s Problem Solving Method in Remedial Math," vol. 3, no. 1 , pp. $97-10 \overline{7}, 2013$.

[3] H. Fatmawati, "Analisis Berpikir Kritis Siswa dalam Pemecahan Masalah Matematika Berdasarkan Polya pada Pokok Bahasan Persamaan Kuadrat," vol. 2, no. 9, pp. 911-922, 2014.

[4] B. Usodo, "Karakteristik Intuisi Siswa SMA dalam Memecahkan Masalah Matematika Ditinjau dari Kemampuan Matematika dan Perbedaan Gender," vol. 1, no. 1, pp. 1-14, 2012.

[5] J. Mansyur, "Teachers' and Students' Preliminary Stages in Physics Problem Solving," Int. Educ. Stud., vol. 8, no. 9, pp. 1-14, 2015.

[6] P. Barniol and G. Zavala, "Force, velocity, and work: The effects of different contexts on students' understanding of vector concepts using isomorphic problems," vol. 20115, pp. 1-15, 2014.

[7] W. Szetala and C. Nicol, "Evaluating Problem Solving in Mathematics," Educ. Leadersh., vol. 49, no. 8, pp. 42-45, 1992.

[8] M. Germain, Y. and Carthy, Bringing the NCTM Standards to Life: Exemplary Practices for Middle School. New York: Routledge, 2013. 